\title{
The Colour Characteristics of Wool Dyed with Plants of Latvia
}

\author{
Aina Bernava, Riga Technical University, Institute of Textile Materials Technologies and Design
}

\begin{abstract}
Dyeing with natural dyes from plant and other organic sources is known since the prehistoric times. In Latvia, natural dyes have been used for the colouring of natural fibres, such as flax, wool, cotton, silk and leather. Plants for the dyeing were collected in autumn in Latvia, used fresh or dried. Mordant ferrous sulphate, copper sulphate pentahydrate, potassium hydroxide, potassium dichromate and acetic acid were used before, during and after dyeing. The quality of dyeing was evaluated using the RGB system.
\end{abstract}

Keywords: Natural Dyes, Wool Yarn, Mordanting, Colour Evaluation.

\section{INTRODUCTION}

Dyeing with natural or vegetable dyes from plant and other organic sources is known since the prehistoric times [1]. Throughout history, people have dyed their textiles using common, locally available materials. In Latvia, natural dyes have been used for the colouring of natural fibres, such as flax, wool, cotton and silk, as well as leather [2].

Nowadays, interest in natural dyes is a result of awareness and demand for natural products [3]. Natural dyes are ecofriendly, biodegradable, non-toxic, and less allergenic in comparison with synthetic dyes [4]. The uncontrolled discharge of synthetic dyes into the aquatic ecosystem is a global environmental concern due to their negative ecotoxicological effects. Dyes obtained from different natural sources have emerged as an important alternative to synthetic dyes [5].

With Latvian plants it is easier to dye beige, pale yellow and pale green shades. Most difficult is to get the pink and blue shade, due to the fact that in our plants this pigment is not found. The dyeing is not sustainable from blueberries, chokeberries and blackcurrants [2].

Natural colorant from the plants was extracted under different operating conditions such as extraction time (45$120 \mathrm{~min})$, temperature (60-90 C) [5] as well as conventional method and ultrasonic technique [6].

To improve the intensity of the natural dyes extracted from plants, a mordant is required. The various substances- mineral (salts, crusts, mud, metal oxides) and organic (urine, animal or vegetable fats, plant's juices and broths) can be considered for mordanting [7]. Different mordants allow different colour ranges for each dyestuff.

Some basic techniques of mordanting have been applied. One of them is pre-mordanting it means that the dye-bath is not altered by adding a mordant. The simultaneous mordanting is a quick method and gives good results with wool when light colours are desired. The post-mordanting is possible to intensify, fix more permanently or modify the shades [7].

Latvian handcraftsmen have been using natural dyes for manufacturing crafts since ancient times. In this study, nontoxic and eco-friendly dyes were extracted from Latvian plants collected during the autumn season, used for wool dyeing and the quality of dyeing result was evaluated.

\section{MATERIALS AND METHODS}

\section{A. Materials.}

$100 \%$ wool yarn (245Tex) produced by "Klippan Saule" Ltd., Latvia was used. Wool was prewashed with a solution of pH neutral liquid laundry detergent "KASTANIS CLASSIC" (JSC "Spodriba", Latvia) before dyeing (liquor ratio 30; dose$2 \mathrm{~g} / \mathrm{l}$ at $30^{\circ} \mathrm{C}$ for $10 \mathrm{~min}$.), rinsed with warm and cold water.

The plants (Tab.1) such as leaves of white chestnut (Ch.), Norway maple (M), apple-tree (A) and vine (V), bush of cowberry $(\mathrm{C})$, heather $(\mathrm{H})$ and plants of common nettle $(\mathrm{N})$ and onion peel $(\mathrm{O})$ were collected in the region of Riga in an autumn and used fresh. Leaves of hemp (He) from experimental fields of Agriculture Science Centre of Latgale, harvested in autumn, were used dried.

\section{B. Chemicals}

Mordants such as ferrous sulphate $\left(\mathrm{FeSO}_{4}\right)$, copper sulphate pentahydrate $\left(\mathrm{CuSO}_{4} * 5 \mathrm{H}_{2} \mathrm{O}\right)$, potassium hydroxide $(\mathrm{KOH})$, potassium dichromate $\left(\mathrm{K}_{2} \mathrm{Cr}_{2} \mathrm{O}_{7}\right)$ and acetic acid $\left(\mathrm{CH}_{3} \mathrm{COOH}\right)$ were used. The doses of mordant were $5 \mathrm{~g} / 1$ and $33 \mathrm{~g} / \mathrm{l}$ in case of $\mathrm{CH}_{3} \mathrm{COOH}$.

\section{Methods}

\section{Preparation of the dyes extract}

Chopped plants were soaked in distilled water (ratio 1:10) $24 \mathrm{~h}$ at room temperature. After boiling $1.5 \mathrm{~h}$ and filtration, dregs were boiled repeatedly at the same water ratio. Both extracts were mixed and used for the dyeing.

\section{Dyeing}

Wool was dyed (Tab.1) (liquor ratio 30) at $80-95^{\circ} \mathrm{C}$ for $60 \mathrm{~min}$, rinsed with warm and cold water, squeezed and dried at room temperature.

\section{Mordanting}

Pre- mordanting (B) before dyeing (liquor ratio 30) in separate bath containing a mordant (title B Chemicals) at $30{ }^{\circ} \mathrm{C}$ for $45 \mathrm{~min}$. was used. Wool was rinsed with water (warm, cold), squeezed and dried. 
Simultaneous mordanting (liquor ratio 30) was done at the time $(\mathrm{T})$ of dyeing in a bath containing a mordant (title B Chemicals) at $80-95^{\circ} \mathrm{C}$ for $60 \mathrm{~min}$. The samples were rinsed with warm and cold water, squeezed and dried at room temperature.
Post-mordanting (title B Chemicals) was used after the dyeing (A) (liquor ratio of 30 ) at $30{ }^{\circ} \mathrm{C}$ for $45 \mathrm{~min}$

TABLE 1

DeSignATION OF SAMPLES, USED Plants, MORDANTS AND METHOD OF MORDANTING,

COLOUR PARAMETERS OF DYED SAMPLES

\begin{tabular}{|c|c|c|c|c|c|c|c|c|}
\hline \multirow[t]{2}{*}{$\mathrm{Nr}$} & \multirow[t]{2}{*}{ Used Plants } & \multirow[t]{2}{*}{ Used Chemicals } & \multirow[t]{2}{*}{ Method of Mordanting } & \multirow{2}{*}{$\begin{array}{l}\text { Designation of } \\
\text { Sample }\end{array}$} & \multirow{2}{*}{$\begin{array}{l}\text { Degree of } \\
\text { Lightness, } \\
\text { L* }^{*}\end{array}$} & \multicolumn{2}{|c|}{$\begin{array}{l}\text { Coordinate of } \\
\text { Colour Vector }\end{array}$} & \multirow[t]{2}{*}{ Hue, $\mathrm{H}$} \\
\hline & & & & & & a* & $b^{*}$ & \\
\hline 0 & Wool & $\begin{array}{l}\text { pH neutral laundry } \\
\text { detergent"Kastanis } \\
\text { Classic" }\end{array}$ & Prewashed & 0 & 79.91 & 3.38 & 3.90 & - \\
\hline 1 & \multirow{2}{*}{$\begin{array}{l}\text { Leaves of } \\
\text { white chestnut }\end{array}$} & $\mathrm{CuSO}_{4} * 5 \mathrm{H}_{2} \mathrm{O}$ & Post-mordanting & Chl_CuSO ${ }_{4} \_\mathrm{A}$ & 49.75 & 6.47 & 16.42 & 1.47 \\
\hline 2 & & $\mathrm{FeSO}_{4}$ & Post-mordanting & $\mathrm{Chl} \mathrm{FeSO}_{4} \_\mathrm{A}$ & 56.71 & 3.98 & 15.89 & 1.5 \\
\hline 3 & \multirow{2}{*}{$\begin{array}{l}\text { Fruits of white } \\
\text { chestnut }\end{array}$} & $\mathrm{CuSO}_{4} * 5 \mathrm{H}_{2} \mathrm{O}$ & Post-mordanting & $\mathrm{Chs}_{-} \mathrm{CuSO}_{4} \_\mathrm{A}$ & 49.82 & 3.76 & 7.88 & 1.33 \\
\hline 4 & & $\mathrm{FeSO}_{4}$ & Post-mordanting & Chs_FeSO ${ }_{4} \_\mathrm{A}$ & 54.90 & 3.60 & 7.65 & 1. 52 \\
\hline 5 & \multirow{2}{*}{$\begin{array}{l}\text { Leaves of } \\
\text { Norway maple }\end{array}$} & - & Without mordant & M & 45.80 & 4.18 & 2.96 & -0.87 \\
\hline 6 & & $\mathrm{FeSO}_{4}$ & $\begin{array}{l}\text { Simultaneous } \\
\text { mordanting }\end{array}$ & M_FeSO $4 \_\mathrm{T}$ & 30.92 & 3.64 & 3.29 & -1.17 \\
\hline 7 & \multirow{2}{*}{$\begin{array}{l}\text { Leaves of } \\
\text { apple-tree }\end{array}$} & $\mathrm{CuSO}_{4} * 5 \mathrm{H}_{2} \mathrm{O}$ & Post-mordanting & $\mathrm{A}_{-} \mathrm{CuSO}_{4} \_\mathrm{A}$ & 50.17 & 3.70 & 14.45 & 1.54 \\
\hline 8 & & $\mathrm{FeSO}_{4}$ & Post-mordanting & $\mathrm{A}_{-} \mathrm{FeSO}_{4} \_\mathrm{A}$ & 40.71 & 2.13 & 9.27 & -1.34 \\
\hline 9 & \multirow{4}{*}{ Leaves of vine } & $\mathrm{CuSO}_{4} * 5 \mathrm{H}_{2} \mathrm{O}$ & Post-mordanting & $\mathrm{V}_{-} \mathrm{CuSO}_{4} \_\mathrm{A}$ & 42.62 & 8.86 & 16.21 & 1.15 \\
\hline 10 & & $\mathrm{FeSO}_{4}$ & Post-mordanting & $\mathrm{V}_{-} \mathrm{FeSO}_{4} \_\mathrm{A}$ & 39.38 & 4.98 & 11.71 & 1.37 \\
\hline 11 & & $\mathrm{FeSO}_{4}$ & Pre-mordanting & $\mathrm{V}_{-} \mathrm{FeSO}_{4} \mathrm{~B}$ & 38.33 & 5.79 & 11.01 & 1.24 \\
\hline 12 & & $\mathrm{~K}_{2} \mathrm{Cr}_{2} \mathrm{O}_{7}$ & $\begin{array}{l}\text { Simultaneous } \\
\text { mordanting }\end{array}$ & $\mathrm{V} \_\mathrm{K}_{2} \mathrm{Cr}_{2} \mathrm{O}_{7}{ }_{-} \mathrm{T}$ & 57.79 & 5.12 & 12.72 & 1.38 \\
\hline 13 & \multirow{4}{*}{$\begin{array}{l}\text { Bush of } \\
\text { cowberry }\end{array}$} & - & Without mordant & $\mathrm{C}$ & 63.46 & 5.88 & 23.70 & 1.45 \\
\hline 14 & & $\mathrm{CuSO}_{4} * 5 \mathrm{H}_{2} \mathrm{O}$ & Post-mordanting & $\mathrm{C}_{-} \mathrm{CuSO}_{4} \_\mathrm{A}$ & 48.21 & 4.23 & 20.85 & 1.52 \\
\hline 15 & & $\mathrm{~K}_{2} \mathrm{Cr}_{2} \mathrm{O}_{7}$ & $\begin{array}{l}\text { Simultaneous } \\
\text { mordanting }\end{array}$ & C_ $\mathrm{K}_{2} \mathrm{Cr}_{2} \mathrm{O}_{7} \mathrm{~T}$ & 44.51 & 6.53 & 23.53 & 1.41 \\
\hline 16 & & $\mathrm{~K}_{2} \mathrm{Cr}_{2} \mathrm{O}_{7}$ & Pre-mordanting & $\mathrm{C} \_\mathrm{K}_{2} \mathrm{Cr}_{2} \mathrm{O}_{7} \mathrm{~B}$ & 53.57 & 7.34 & 29.47 & 1.42 \\
\hline 17 & \multirow{2}{*}{$\begin{array}{l}\text { Bush of } \\
\text { heather }\end{array}$} & - & Without mordant & $\mathrm{H}$ & 46.78 & 5.41 & 16.81 & 1.41 \\
\hline 18 & & $\mathrm{CuSO}_{4} * 5 \mathrm{H}_{2} \mathrm{O}$ & Pre-mordanting & $\mathrm{H}_{-} \mathrm{CuSO}_{4} \_\mathrm{B}$ & 55.67 & 2.92 & 16.98 & -1.54 \\
\hline 19 & \multirow{2}{*}{ Plants of nettle } & $\mathrm{CuSO}_{4} * 5 \mathrm{H}_{2} \mathrm{O}$ & Post-mordanting & $\mathrm{N}_{-} \mathrm{CuSO}_{4} \_\mathrm{A}$ & 51.12 & 5.86 & 20.08 & 1.42 \\
\hline 20 & & $\mathrm{FeSO}_{4}$ & Post-mordanting & N_FeSO ${ }_{4} \_\mathrm{A}$ & 51.25 & 3.99 & 9.23 & 1.46 \\
\hline 21 & \multirow{3}{*}{ Onion peel } & - & Without mordant & $\mathrm{O}$ & 54.06 & 9.73 & 18.24 & 1.15 \\
\hline 22 & & $\mathrm{KOH}$ & Post-mordanting & O_KOH_A & 34.05 & 12.13 & 20.24 & 1.08 \\
\hline 23 & & $\mathrm{KOH}$ & $\begin{array}{l}\text { Simultaneous } \\
\text { mordanting }\end{array}$ & O_KOH_T & 35.58 & 13.55 & 23.02 & 1.08 \\
\hline 24 & \multirow{5}{*}{$\begin{array}{l}\text { Leaves of } \\
\text { Hemp }\end{array}$} & - & Without mordant & $\mathrm{He}$ & 69.14 & 3.07 & 18.05 & -1.51 \\
\hline 25 & & $\mathrm{CH}_{3} \mathrm{COOH}$ & $\begin{array}{l}\text { Simultaneous } \\
\text { mordanting }\end{array}$ & $\mathrm{He} \_\mathrm{CH}_{3} \mathrm{COOH} \_\mathrm{T}$ & 62,04 & 5,79 & 15.01 & 1.38 \\
\hline 26 & & $\mathrm{~K}_{2} \mathrm{Cr}_{2} \mathrm{O}_{7}$ & $\begin{array}{l}\text { Simultaneous } \\
\text { mordanting }\end{array}$ & $\mathrm{He} \mathrm{K}_{2} \mathrm{Cr}_{2} \mathrm{O}_{7} \mathrm{~T}$ & 61,46 & 4,56 & 11.92 & 1.47 \\
\hline 27 & & $\mathrm{CuSO}_{4} * 5 \mathrm{H}_{2} \mathrm{O}$ & $\begin{array}{l}\text { Simultaneous } \\
\text { mordanting }\end{array}$ & $\mathrm{He}_{-} \mathrm{CuSO}_{4}{ }_{-} \mathrm{T}$ & 59.63 & -0.53 & 10.03 & -0.87 \\
\hline 28 & & $\mathrm{FeSO}_{4}$ & $\begin{array}{l}\text { Simultaneous } \\
\text { mordanting }\end{array}$ & $\mathrm{He} \_\mathrm{FeSO}_{4} \mathrm{~T}_{\mathrm{T}}$ & 62.38 & 5.74 & 3.52 & $-0,61$ \\
\hline
\end{tabular}




\section{Colour Test}

The samples representing variations (Tab.1) were carried out in the spectral width from 400 to $700 \mathrm{~nm}$ (CQA Easy Color V3.0 Pocketspec Technologies Inc, USA), using CIE L* $a^{*} b^{*}$ measuring system, what allows to determine the

coordinates of colour vectors $a^{*}, b^{*}$ and $L^{*}$ - the degree of lightness in the colour space [8]. $\left(\Delta \mathrm{L}^{*}\right)$, common colour differences $(\Delta \mathrm{E})$, chroma $(\mathrm{C})$ and hue $(\mathrm{H})$ were calculated according to the following common formulas [9].
$\Delta L^{*}=L_{\text {sample }}^{*}-L_{s \tan \text { dard }}$

$\Delta E=\sqrt{\left(\Delta L^{*}\right)^{2}+\left(\Delta a^{*}\right)^{2}+\left(\Delta b^{*}\right)^{2}}$

$C=\sqrt{\left(a^{*}\right)^{2}+\left(b^{*}\right)^{2}}$

$H=\operatorname{arctg}\left(\frac{b^{*}}{a^{*}}\right)$

$\mathrm{L}^{*}$ sample- the degree of lightness of sample,

$\mathrm{L}^{*}$ standard - the degree of lightness of standard,

$\Delta \mathrm{a}^{*}, \Delta \mathrm{b}^{*}$-average of coordinates of colour vector.

Parameters of dyed samples were compared with the prewashed wool as standard was used.

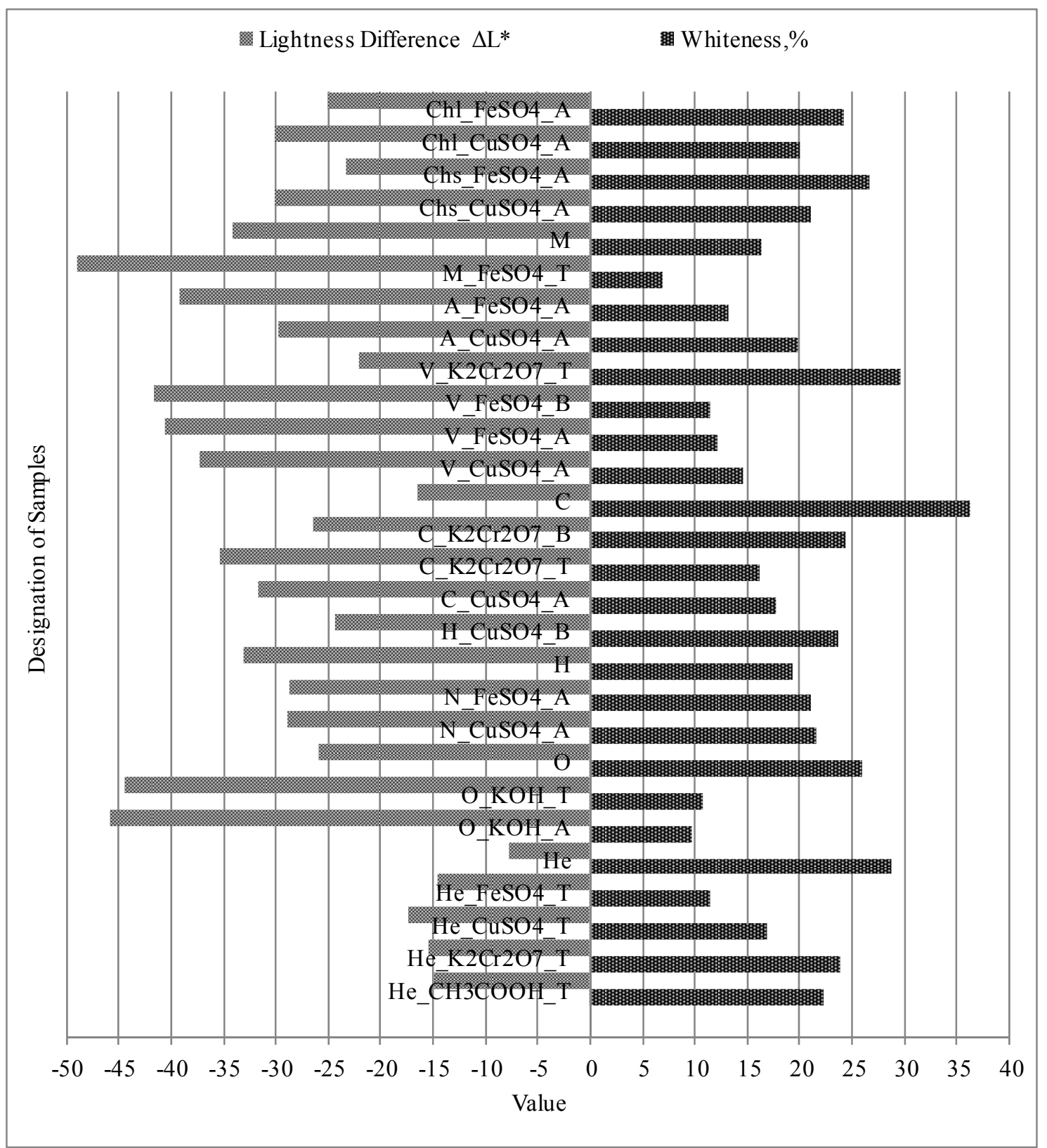

Fig.1. Lightness Difference and Whiteness of Dyed Samples 


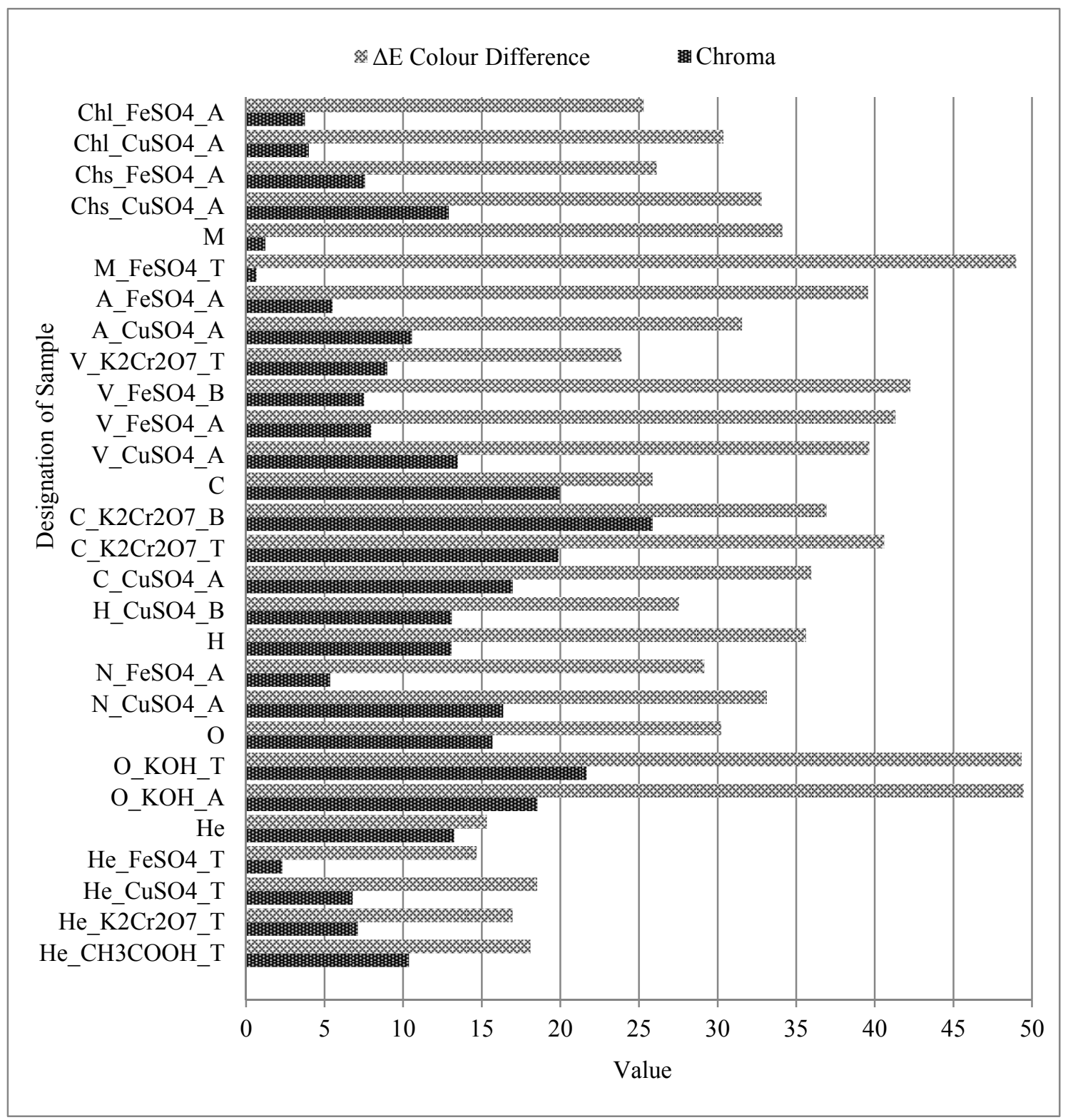

Fig.2 Colour Difference and Chroma of dyed samples

\section{Whiteness Test}

Whiteness of dyed samples was determined with Rhopoint Novo-Shade Duo 45/00 reflectometer (Rhopoint Instrumentation Ltd, UK). Preparing and testing of samples according to user manual [10] was performed.

\section{RESULTS AND DISCUSSION}

The wool samples dyed with the above- mentioned Latvian plants without and with different mordants using and applying the three mordanting methods, gave mainly yellowish, brownish, greenish and grey colours.
Colour coordinates (Tab.1) a* (-0.5-13.6) and $b^{*}(2.9-29.5)$ characterise redness $\left(+a^{*}\right)$, greenness $\left(-a^{*}\right)$, yellowness $\left(+b^{*}\right)$ and blueness $\left(-b^{*}\right)$ [11]. Higher values of $a^{*}, b^{*}$ were obtained with mordant $\mathrm{K} 2 \mathrm{Cr} 2 \mathrm{O} 7$ use and pointed at ruddy and yellowy shade of the colour of the sample.

Values of degree of lightness (Tab.1) are positive. The colour of hemp without mordanting (69.14) is a bit darker, than prewashed wool, but maple (45.80) is still darker than the preliminary sample. However, the lightness of hemp with FeSO4 (62.38) use is slightly deeper than without mordanting (69.14). The major decrease of lightness (30.92) has been observed with maple and same mordant application. It indicates that the main factor is used plant. 
The value of hue (Tab.1) indicates the variety of colour shades of dyed wool. The sample with hue value $(-0.87)$ indicates dark grey colour with maple as well as the dun colour with hemp with $\mathrm{FeSO} 4$ use (simultaneous-mordanting). The value of hue (-1.5) points at greenish-grey colour of heather with the same mordant and method use, as well as light yellowish colour of hemp sample. Positive values of hue (1.5) point at snuff colour (hemp with $\mathrm{K} 2 \mathrm{Cr} 2 \mathrm{O} 7$ simultaneousmordanting), green hay colour (cowberry and apple with $\mathrm{CuSO} 4)$ as well as dark straw colour (chestnut with $\mathrm{CuSO} 4$ ). The significant change of hue has been observed with one plant use with different mordants. It indicates, that important for hue is both- use of plant and mordant.

Values of the lightness difference (Fig.1) characterize the difference between lightness of the sample and lightness of the standard (prewashed wool). For samples without mordant use the lowest difference of lightness (-7.74) is for hemp (beige colour), the higher (34.11) is for maple (medium grey colour). For samples with mordant use, lower difference of lightness is (-14.49) for samples dyed with white chestnut (hay colour) with ferrum sulphate (simultaneous mordanting). The greater difference of lightness (-49.0) is for maple (dark gray) with ferrous sulphate use (simultaneous mordanting), as well the lower whiteness index $(6.9 \%)$ has been set for this sample, due to dark colour.

For comparison and explaining the obtained results, the whiteness index, \% (Fig.1) of wool samples was determined from black ( $0 \%$-no reflectance) to brilliant white $(100 \%$-full reflectance). The value of whiteness of prewashed wool (36.5) as standard was used. With ferrous sulphate and cowberry has been observed whiteness index 36.3\% (light hay colour), while about $19 \%$ with use of vine (dark beige colour) and potassium dichromate (simultaneous mordanting). It indicates, that a greater influence on the lightness difference and the whiteness was observed from the used mordant.

The value of colour difference (Fig.2) denotes a common colour difference of the sample. Without mordant use the lowest difference (15.33) is for hemp, the highest (35.61) is for heather. For samples with mordant use, the lower value (14.67) is obtained for hemp with FeSO4 use (simultaneous mordanting). The influence of ferrum sulphate use on colour difference value in this case is about $18 \%$, while with maple use, the same mordanting method - about 30\%. With potassium hydroxide and onion (post-mordanting) use the highest difference of colour $(40 \%)$ was observed. The influence of copper sulphate pentahydrate with hemp is about $18 \%$. For potassium dichromate with cowberry- $39 \%$, while with hemp- $10 \%$ difference of colour was observed. The most significant influence on colour difference value has been achieved from the used mordant.

Chroma (Fig.2) is a measure of intensity or saturation of any hue. The lowest value of chroma (Fig.2) of the sample without mordanting is for maple (1.23) greyish beige colour, whereas light hay colour is with cowberry (16.96). For maple mordanted simultaneously with ferrous sulphate the lowest value of chroma (0.66) has been observed, the dark gray shade of sample. The higher parameter of chroma (25.9) is for cowberry, mordanted with potassium dichromate before dyeing (green shade) and onion (21.7) with potassium hydroxide (brown shade). By the reduction of the saturation of hue, the colour turns into different grey shades due to the used mordant. From the used plants the intensity of chroma observed as different shades of green, yellow or brown colour.

\section{CONCLUSION}

The plants of Latvia were used for wool dyeing without and with the use of different mordants and application of three mordanting methods.

The main factor of influence on lightness is a used plant. The darkness of all samples indicated the negative lightness difference.

The most significant influence on colour difference has been achieved from used mordant and the positive values of colour difference are due to the distinction of common colour difference of each colour.

The whiteness index indicates, that greater influence on the lightness difference and the whiteness has been observed from the used mordant.

Positive and negative values of hue pointed at various shades (yellowish, brownish, greenish and grey colours) of colouring.

The value of chroma pointed at influence of mordant and plant use on colour saturation of dyeing as different shades of green, yellow or brown colour, but by decrease of saturation the colour turns into different grey shades.

The colour parameters are dependent on used plants and mordants more than applying of mordanting method.

The use of the RGB system for the evaluation of quality of dyeing is a new method for craftsmen of Latvia for the dyeing colour characterization.

\section{ACKNOWLEDGMENTS}

The research has been supported by the Latvian Council of Science, Cooperation Project No. 10.0040.

\section{REFERENCES}

1. Mirjalili, M., Nazarpoor, K., Karimi, L. Eco-friendly dyeing of wool using natural dye from weld as copartner with synthetic dye. Journal of Cleaner Production, vol. 19, No.9-10, pp.1045-1051. http://dx.doi.org/10.1016/j.jclepro.2011.02.001

2. Madre, I. Krāsošana ar augu krāsvielām, Rīga: Avots, 1999.

3. Nasirizadeha, N., Dehghanizadeha, H., Yazdanshenasa, M.E., Rohani Moghadam, M., Karimia, A. Optimization of wool dyeing with rutin as natural dye by central composite design method. Industrial Crops and Products. 2012, vol.40, pp.361-366. http://dx.doi.org/10.1016/j.indcrop.2012.03.035

4. Ghouila, H., Meksi, N., Haddar, W., Mhenni, M.F., Jannet, H.B. Extraction, identification and dyeing studies of Isosalipurposide, a natural chalcone dye from Acacia cyanophylla flowers on wool. Industrial Crops and Products. 2012, vol.35, issue.1, pp.31-36.

5. Sinha, K., Das Saha, P. Extraction of natural dye from petals of Flame of forest (Butea monosperma) flower: Process optimization using response surface methodology (RSM). Dyes and Pigments. 2012, vol. 94, isssue. 2, pp. 212-216. 
6. Kamel, M.M., El-Shishtawy, Reda M., Yussef, B.M., Mashaly, H. Ultrasonic assisted dyeing: Dyeing of wool with lac as a natural dye. Dyes and Pigments. 2005, vol.65, isssue. 2, pp. 103-110.

7. Cardon, D., Natural Dyes, Sorces, Tradition, Technology and Science, Archetype Publications Ltd, 2007, pp10-16, ISBN-101-904982-00-X.

8. Šutka, A., Borisova, A., Kleperis, J., Mežinskis, G., Jakovḷevs, D., Juhnneviča, I. Effect of Nickel Addition on Colour of Nanometer Spinel Zinc Ferrite Pigments. Journal of Australian Ceramic Society. Vol.48, 2012, no. 2, pp 150-155.

9. Bernava, A., Reihmane, S. Usage of Enzymatic Bioprocessing for Raw Linen Fabric Preparing. Textiles and Light Industrial Science and Technology. Vol. 2, 2013, issue. 3, pp.131-136.

10. Rhopoint Novo-shade $\mathrm{Duo}^{\mathrm{tm}} 45 / 00$ reflectometer. User Manual [online]. [viewed 18 September 2013] Available from: www.rhopointinstruments.com

11. Abd Razak, N., Marsinah Tumin, S., and Tajuddin, R. Effect of Temperature on the Color of Natural Dyes Extracted Using Pressurized Hot Water Extraction Method. American Journal of Applied Sciences. Vol. 8, issue 1, 2011, pp.45-49. http://dx.doi.org/10.3844/ajassp.2011.45.49

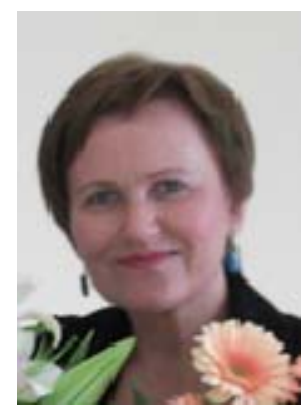

Aina Bernava, Professional Master Degree in Material Design and Technology, Riga Technical University; Institute of Textile Materials Technologies and Design , 2011. Master Degree from the Latvian Chamber of Crafts in 2004.

Research Assistant at Riga Technical University, Institute of Polymer Materials since 2007. Contractor of Ltd. MNKC- LIAA Research Project of Natural Fibers and Flax Fibers Properties since 2013. Researcher in National Scientific projects of the Institute of Polymer Materials since 2011.

Field of research is connected with innovative weaved textile structures processing and textile material modification for the use in ordinary textiles and composite materials. More than 30 years of practical experience in the field of fabric design and hand-made weaving.

Address: Riga Technical University, Institute of Polymer Materials

Azenes Str. 14/24, LV-1048, Riga, Latvia.

E- mail: aina.bernava@inbox.lv

\section{Aina Bernava. Ar Latvijas augiem krāsotas vilnas krāsojuma raksturojums.}

Pasaulē krāsošana ar dabas krāsvielām ir zināma kopš aizvēsturiskiem laikiem. Latvijā tās pielieto dabisko škiedru- linu, vilnas, kokvilnas un zīda, kā arī ādas krāsošanai. Dabas krāsvielas ir videi un cilvēkam draudzīgākas nekā sintētiskās krāsvielas. Mūsdienās interese par dabiskiem produktiem palielina pieprasījumu krāsošanai ar dabas krāsvielām.

Pētījumā krāsota 100\% vilna (245 Tex, SIA "Klippan Saule", Latvija), kas mazgāta ar pH neitrālu mazgāšanas līdzekli "KASTANIS CLASSIC"(AS "Spodrība", Latvija). Augu lapas- (kḷavu, ābeles, mežvīteņu, kaņepju un kastaņas), mētras (brūkleṇu un viršu), kā arī sīpolu mizas ievāktas rudenī. Krāsošanas šķīduma sagatavošanai nepieciešams $1.0 \mathrm{~kg}$ svaigu vai $0.5 \mathrm{~kg}$ kaltētu augu uz $0.1 \mathrm{~kg}$ dzijas (Vannas modulis 30 ). Tos sasmalcina, pārlej ar aukstu ūdeni (1:10) un notur 24h istabas temperatūrā, tad $1.5 \mathrm{~h}$ vāra. Augu izvilkumu nokāš, atkārtoti pārlej ar tādu pat ūdens daudzumu un procedūru atkārto. Abus augu novārījumus salej kopā. Dziju krāso $80-95^{\circ} \mathrm{C}$ temperatūrāa, 60 min. Kodina, atbilstoši receptūrai $(5 \mathrm{~g} / 1)$ ar dzelzs sulfātu, vara sultātu (5 hidrātu), kālija hidroksīdu un kālija dihromātu vai etiḳskābi (33 g/l) pirms, pēc krāsošanas $\left(30^{\circ} \mathrm{C}, 45\right.$ min), vai krāsošanas laikā.

Paraugu krāsu atšķirības analizē ar CQA Easy Color V3.0 Pocketspec (Technologies Inc, ASV) krāsu testeri, izmantojot RGB sistēmu, kas l̦auj noteikt krāsu vektoru koordinātes CIElab-76 krāsu telpā. Pēc iegūtajiem mērījumiem aprēķina gaišuma atšķirī̄bu $\left(\Delta \mathrm{L}^{*}\right)$, krāsu atšķirību $(\Delta \mathrm{E})$, nokrāsu $(\mathrm{C})$ un krāsu toni $(\mathrm{H})$. Krāsojuma baltuma pakāpi (\%) nosaka ar virsmas atstarošanas mērītāju Rhopoint Novo-Shade Duo 45/00 (Rhopoint Instrumentation Ltd, UK).

Secinājumi: Visi izpētēe izmantotie Latvijas augi ir piemēroti vilnas krāsošanai, Krāsojot iegūtas zalganas, pelēcīgas vai dzeltenīgas nokrāsas izkrāsojumi. Krāsu atškirīibu, kā arī krāsu toni vairāk ietekmē pielietotais augs nekā izvēlētais kodinātājs vai kodināšanas metode, ko apliecina vilnas izkrāsojumu primārā krāsu kvalitātes pārbaude. Krāsa ir atkarīga no izmantotajiem augiem un kodinātājiem.

\section{Айна Бернава. Цветовая характеристика шерстяной пряжи, окрашенной природными красителями Латвии.}

Крашение с природными красителями известно с доисторических времён. В Латвии природные красители примененяются для крашения природных волокон - льна, шерсти, хлопка и шелка, а также кожи. Эти красители более экологичны по сравнению с синтетическими красителями. В наше время повышается интерес к экологическим продуктам, и в связи с тем к использованию природных красителей.

Для крашения применена 100\% шерстяная пряжа (245 текс, Латвия "Klippan Saule"), которая выстирана pH-нейтральным моющим средством "KASTANIS CLASSIC" (Латвия, "Spodriba"). Листья (клён, яблоня, ломонос, конопля, каштан), мята (брусника и вереска), также шелуха луковиц собранных осенью, применяют в высушенном виде. Для подготовки красильного раствора необходимо 1 кг свежих или 0.5 кг высушенных растений на 0.1 кг пряжи (модуль ванны 30), которые измельчают, заливают холодной водой (1:10), выдерживают 24 часа при комнатной температуре, кипятят 1,5 часа. Получают отвар, и процесс снова повторяют. Оба раствора сливают вместе. Крашение шерстяной пряжи производят при тепературе $85-90^{\circ} \mathrm{C}$ в течение 1 часа, полощут тёплой и холодной водой, сушат при комнатной температуре. Для травления шерсти применяют сульфат железа, сульфат меди 5- водный, дихромат и гидроксид калия (5 г/л), а также уксусную кислоту (33 г/л) перед/после (при температуре $30^{\circ} \mathrm{C}, 45$ минут) или во время крашения шерсти.

Для оценки окрашенной пряжи использован прибор CQA Easy Color V3 Pocketspec (Technologies Inc, CША) и система RGB, которая позволяет установить координаты цветовых векторов в цветовом пространстве CIELAB-76. Полученные результаты измерений использованы для расчетов светлого тона ( $\left.\Delta \mathrm{L}^{*}\right)$ цветового различия $(\Delta \mathrm{E})$, оттенка $(\mathrm{C})$ и тона цвета $(\mathrm{H})$. Степень белизны $(\%)$ окрашенной пряжи измеряет аппаратом Rhopoint Novo-Shade Duo $45 / 00^{\circ}$ (Rhopoint Instrumentation Ltd, UK).

Вывод: все использованные растения Латвии применяются для крашения шерстяной пряжи. Первичная проверка качества окрасок показывает, что цветовые параметры зависят от применяемых растений и протрав. 